\title{
Professional Disease Management Guide for Ornamental Plants 1
}

\section{S. D. Bledsoe, P. F. Harmon, and R. J. McGovern²}

The ornamental plant industry thrives in Florida because of the warm, humid environment that makes Florida a gardener's paradise and a compatible location to mass produce numerous species of plants. These ideal conditions are also suitable for the development of a wide variety of plant pests including pathogenic bacteria, fungi, and viruses. Mild winters in Florida also facilitate survival of some insects that can spread plant pathogens, especially viruses. Growers are challenged to develop the most efficient production plan possible incorporating as many tactics as possible to maximize plant health and minimize opportunities for pest and disease outbreaks - a concept known as integrated pest management (IPM). This publication is intended to be used by growers, landscape professionals, and other pest control operators as a reference for managing diseases of ornamental plants. Management tactics are outlined under the following key components of an IPM program: prevention, cultural control, scouting, physical control, biological control, and chemical control. Tables 1 - 4 contain important information on commercial products currently available for the management of diseases in ornamental plants. In addition, a list of useful websites and references is provided at the end of this document to supplement the information provided herein.

\section{Disease Prevention}

Once symptoms of a disease or pest problem are evident, management can be difficult, costly, or maybe impossible. Some basic management practices can help prevent pest problems from occurring in the first place. The following precautions can reduce the likelihood of plant disease development and spread.

\section{Exclusion}

Exclusion implies that healthy plants or pathogen-free planting media are kept in an isolated area that excludes plant pathogens. Plants are often grown in a nursery or greenhouse where care is taken to ensure that planting stock and media are disease and pathogen-free. When ordering seeds, bulbs, or tubers, find out if they are certified to be pathogen-free. If possible, purchase planting media that has been pasteurized to kill plant pathogens and

1. This document is PP202, one of a series of the Plant Pathology Department, Florida Cooperative Extension Service, Institute of Food and Agricultural Sciences, University of Florida. Original publication date October 2004. Visit the EDIS Web Site at http://edis.ifas.ufl.edu.

2. S.D. Bledsoe Doctor of Plant Medicine graduate, P.F. Harmon, assistant professor, R.J. McGovern, professor, Plant Pathology Department, Cooperative Extension Service, Institute of Food and Agricultural Sciences, University of Florida, Gainesville, 32611.

The use of trade names in this publication is solely for the purpose of providing specific information. UF/IFAS does not guarantee or warranty the products named, and references to them in this publication does not signify our approval to the exclusion of other products of suitable composition. All chemicals should be used in accordance with directions on the manufacturer's label.

The Institute of Food and Agricultural Sciences (IFAS) is an Equal Employment Opportunity - Affirmative Action Employer authorized to provide research, educational information and other services only to individuals and institutions that function without regard to race, creed, color, religion, age, disability, sex, sexual orientation, marital status, national origin, political opinions or affiliations. For information on obtaining other extension publications, contact your county Cooperative Extension Service office. Florida Cooperative Extension Service / Institute of Food and Agricultural Sciences / University of Florida / Larry R. Arrington, Interim Dean 
pests. All media should be stored in original bags until use, or in covered containers to prevent contamination by plant pathogens. Some procedures for reducing pathogen populations in native soil and planting stock are listed below (see section on Physical Control). If new plants are brought into a production system from an outside source, it is wise to isolate them from other plantings for a period of time to make sure they are free of pathogens and other pests.

\section{Avoidance}

Precautions taken that enable plants to escape pathogens that are present in the growing environment are known as avoidance measures.

Avoid plant damage - Take care not to damage plants during installation and maintenance of the landscape. Damaged roots and other plant parts provide sites of entry for disease-causing organisms. Rough handling of root balls can cause broken roots and interfere with the plant's ability to take up water and nutrients. Make sure the plants are secured during transport and placed gently (not dropped) into planting holes. Once established, avoid damage to trees and shrubs from line trimmers. Such damage interferes with the vascular system of the plant in addition to creating an infection court.

Over-pruning weakens trees and shrubs, making them more susceptible to attack by pathogens and pests. No more than $30 \%$ of the foliage should be removed at one time. Unless absolutely necessary, do not remove branches that are more than about half the diameter of the trunk. Large wounds take longer to heal and are more likely to decay than small wounds. Using tree-wound paint on tree pruning wounds may provide protection against insect pests. The microenvironment beneath bubbling or deteriorating paint can provide an ideal niche for damaging microorganisms.

Using "immature" planting mixes that contain incompletely composted bark or fresh manure may result in damage to plants from the release of heat and toxic compounds. Manure should be completely dry and loose before adding to planting mix. Be sure to thoroughly combine all constituents into a uniform blend. If in doubt, pre-mixed potting soils purchased wholesale, at nurseries, or in garden centers provide an alternative to mixing your own.

Insects and nematodes cause feeding damage that provides ideal sites of entry for many pathogenic fungi and bacteria. Some may also spread viruses, for example western flower thrips and five other thrips species can transmit tomato spotted wilt virus to many plants including chrysanthemum, gloxinia, and impatiens. The stubby root nematode can transmit tobacco rattle virus to several ornamental plants including gladiolus, iris, tulip, and orchid.

Maintaining these organisms below damaging levels will reduce feeding damage, help maintain plant health, and may also reduce the incidence of certain insect- and nematode-vectored plant pathogens.

Manipulate time of planting - Manipulating the growing period to a time when climatic conditions do not favor disease development can help avoid losses. This may be a good option for plants with seasonal versatility and no resistant varieties. Pentas are very susceptible to Phytophthora root rot and blight during warm and wet weather. Planting pentas either before or after the rainy season is a good way to avoid losses.

\section{Sanitation}

Sanitation practices are "cleanliness" measures that can reduce unintentional spread of plant pathogens from diseased to healthy plants directly through mechanical transmission or indirectly from pathogen reservoirs.

\section{Avoid mechanical transmission of pathogens -} Hands and pruning tools can be readily contaminated when working with diseased plants, especially if the causal agent is bacterial, viral, or present in the vascular system (i.e. vascular wilts). Fusarium wilt of queen palms is a devastating disease which can be transmitted through pruning, thus readily spreading to other queen palms in a nursery or landscape.

Routinely sanitize all items which come into contact with plants, soil, or debris. A 10- to 20-percent solution of household bleach in water makes a good disinfectant for tools and soles of shoes but is quite corrosive. Examples of commercial disinfectants marketed toward plant production personnel include Consan Triple Action 20, Green Shield, and Physan 20. Dispensers for hands, tools, and foot baths should 
be set up at production house entrances. Hand sanitizers typically contain alcohol and should also be provided in hand dispensers. Washing followed by steam sterilization is an excellent method of reducing pathogen populations on trays, pots, and other production tools. Read and follow the temperature recommendations in manufacturers' guidelines to avoid heat damage. The use of plastic transplant tray liners may also reduce the spread of disease.

Concrete walkways in production houses are helpful because they can be regularly cleaned and disinfested with ease.

Eliminate pathogen reservoirs - Always move diseased plants away from healthy plants and either destroy them or treat them in an isolated area. Plant debris and cull piles are excellent reservoirs for plant pathogens and should be kept away from and downwind of healthy plants and production areas. Personnel should disinfest hands, shoes, and tools after handling rogued, diseased, or decaying plant material before resuming regular duties.

Weeds often harbor pathogens and insects that spread them. Keep weeds suppressed in landscapes, plant production systems, and, as feasible, in surrounding areas. Weed control also reduces competition for water and nutrients and increases air circulation. The use of mulch can help control weeds, improve soil structure, and increase water retention in the soil.

Occasionally plant pathogens are inoculated onto healthy plants through irrigation systems. This commonly occurs when irrigating with surface water from ditches or holding ponds or when irrigating with an ebb-and-flow system. Treatment with ultraviolet light or a chemical sanitizer can reduce pathogens in contaminated irrigation water.

\section{Cultural Control}

Cultural control means employing good horticultural practices to optimize plant health and decrease plant stress, which in turn decreases the likelihood of disease development.

\section{Proper Cultivation}

The first line of defense in the management of plant pest problems is to provide the required conditions for optimal plant growth and development. Plants are often transplanted in certain locations within landscapes solely for aesthetic purposes. The soil type, soil porosity, sunlight exposure, soil $\mathrm{pH}$, and microclimate of the location should all be considered before a plant species is chosen to avoid conditions that are not conducive for healthy growth. Planting in improper locations can increase plant stress and the likelihood of pest problems. This may lead to more frequent pesticide applications, which may be ineffective and increase labor costs. Transplants are particularly vulnerable to plant pathogens during the first few weeks after planting and may require special care to prevent disease outbreaks.

\section{Fertilization and Irrigation}

Adequate fertilization is needed to avoid nutrient deficiencies and keep plants healthy enough to resist and recuperate from diseases. Too much nitrogen, however, can encourage excessive growth of new shoots, which may be more susceptible to plant pathogens than "hardened" more mature growth. One method in the control of fireblight, a bacterial disease of some ornamental fruit trees, is to decrease nitrogen fertilization and irrigation to inhibit the formation of new shoots where the pathogen may attack. In extreme cases, over-fertilization can also cause an excess of soluble salts in the soil. When this happens, scorching of the leaves or "salt burn" may occur because damaged plant roots cannot take up enough water. Do not assume that more is better regarding the application of fertilizers and chemicals to plants; always follow label rates.

Soils with poor drainage will become waterlogged due to over-irrigation. The lack of oxygen in these conditions causes many root cells to collapse, diminishing plant uptake of water and nutrients. Other cells may become non-selective, allowing toxic metals and substances to be taken up by the plant. Many of these plant poisons, such as nitrites, are produced by microorganisms that thrive in wet (anaerobic) conditions. Further damage occurs from organisms known as facultative parasites that 
are attracted to decaying tissue. Most ornamental plants, especially succulent annuals, lack vigor, will wilt, and have leaves that are pale green or yellowish in waterlogged conditions. Some plants have mechanisms or specialized structures adapted to survival in wet soils. See "Landscape Plants for Wet Sites" under the section Useful Websites to choose appropriate plants for wet conditions.

Prolonged leaf wetness should be avoided to minimize foliar diseases. Adequate plant spacing promotes better air circulation, thereby decreasing periods of leaf wetness. Early morning irrigation, sub-irrigation, or the use of a drip system is also recommended. Water quality varies depending on the source and should be tested to be sure $\mathrm{pH}$ and soluble salts are at acceptable levels for healthy plant growth.

\section{Host Resistance}

Cultivars of ornamental plants generally are not selected based on their resistance to plant pathogens. However, differences in relative susceptibilities of cultivars to some pathogens exist and should be considered when and where appropriate. Antique roses, for example, are generally more tolerant of black spot and other diseases that infect roses than most of the more recently-developed rose hybrids. "Natchez" is a cultivar of crape myrtle that is commonly used in Florida because of its resistance to powdery mildew.

Systemically acquired resistance (SAR) has shown promise in reducing disease in a number of crops. This phenomenon is a reaction in a plant that is triggered by various substances including salicylic acid, chitosan, and monopotassium phosphate. Applications of certain microorganisms including the plant-growth promoting rhizobacteria Pseudomonas and non-pathogenic isolates of Fusarium oxysporum have also induced SAR. A bacterial protein, harpin, is commercially produced and sold under the trade name Messenger ${ }^{\circledR}$ and may offer some protection against plant pathogens in food commodities, trees, ornamentals, and turfgrasses. For more information on harpin, see References and Useful Websites.

\section{Crop Rotation}

Many plant pathogens only cause disease on a narrow range of closely-related hosts. Continuous cultivation of the same types of plants in an area for long periods of time can result in elevated populations of pathogens and other pests in the soil. Periodic rotation of plants that are susceptible to different pathogens may decrease populations of harmful organisms and reduce the incidence of these problems. Pest outbreaks tend to spread quickly within monoculture systems. When appropriate, use plants of many different families, species, or at least cultivars within an area. Plant diversity will decrease damage from pathogens and pests that attack specific kinds of plants.

\section{Scouting}

Monitoring for plant problems on a routine basis is the cornerstone of any IPM program and is essential in detecting early pest infestations to prevent economic loss. It is important to correctly ascertain the cause(s) of plant problems so that appropriate measures can be taken to correct them. This can be tricky because sometimes plants respond in similar ways to different types of stresses. Before disease management steps are taken, other possibilities such as insect or mite damage, nutrient or water imbalances, pesticide damage, etc. should be ruled out. If you don't know the recent history of the plant, ask questions and observe the surroundings to obtain clues that could lead you to a correct diagnosis.

\section{Signs and Symptoms}

Symptoms of plant diseases are often similar to damage caused by abiotic stresses. The ability to distinguish between the two is important. One should also be able to recognize characteristics of healthy plants such as normal speckling, spotting or variegation that may be confused with disease symptoms.

Signs refer to some part of a pathogen and are visible during certain environmental conditions. Signs are typically more difficult to find, but include felty or moldy fungal sporulation, cobweb-like fungal growth (mycelia), fruiting bodies [i.e. mushrooms (large), pycnidia (tiny)], sclerotia, and bacterial ooze. 
There are several references with color pictures illustrating common diseases of ornamental plants (see References and Useful Websites) that may be helpful. If in doubt, contact your local extension agent, university specialist, or a professional consultant for advice. A digital image of a plant disease sample can be submitted to university specialists free of charge by using the Distance Diagnostic and Identification System (DDIS) through UF/IFAS extension (http://ddis.ifas.ufl.edu/). Some disease problems can be identified from a picture, but most will need to be sent to a UF/IFAS or commercial diagnostic clinic for correct diagnosis. This fee-based service will ensure an accurate diagnosis and provide valuable documentation of the problem. Ask if digital diagnosis is available from your county extension office.

\section{Thresholds}

The presence of a pest or disease may not always require treatment. Over time a level of damage considered economically or aesthetically unacceptable (i.e. economic threshold) should be set, as well as a damage level at which action must be taken to prevent reaching this point (i.e. action threshold). In most cases, there are no set recommendations for thresholds because various systems differ widely in conditions that affect disease pressure and in tolerances of plant damage. In general, the threshold for damage to ornamental plants is very low or zero because of inherent aesthetic considerations.

\section{Record-keeping}

It is wise to document all management practices as well as pest and disease outbreaks including conditions under which they occur, control measures taken (rates, number of applications, effectiveness, etc.), and any other information that may be useful in predicting and managing problems in the future. Keep log sheets in chemical/fertilizer sheds and require employees to document pertinent information such as his/her name, date, chemical name, rate, amount, sprayer used, and site each time an application is made. Besides being required by laws regulating pesticide usage, good records can aid in problem-solving and may provide legal support in cases of false allegations.

\section{Physical Control}

Physical control of disease-causing organisms is obtained through mechanical procedures applied directly to plants or substrates that reduce or eradicate pathogen populations.

\section{Steam Sterilization}

Steam has been used to disinfest soil for over 100 years, and is practical for the sterilization of soil to be used for potting and transplanting and for intensive in-soil production of high value crops. An application of aerated steam to maintain a uniform soil temperature of $60-70^{\circ} \mathrm{C}\left(140-158^{\circ} \mathrm{F}\right)$ for 30 minutes is sufficient to eliminate most disease-causing organisms present in the soil. Be sure the soil is free of clods, large pieces of plant debris, and excessive moisture which if present will hamper the penetration of the steam.

\section{Soil Solarization}

Soil solarization is an option for managing soilborne pests in production systems and sunny landscape settings during periods with little cloud cover and rain. This technique utilizes clear plastic to trap the radiant energy of the sun, which heats the soil to temperatures sufficient to destroy many plant pathogens and other pests without completely eliminating beneficial organisms. Soil solarization is often used when producing high-quality bedding plants such as cut flowers.

\section{Hot Water Treatment}

Seeds, bulbs, tubers, and cuttings can be immersed in hot water to kill potential pests including pathogens. Daffodil and Easter lily bulbs are commonly treated with hot water to kill any nematodes that may be present. It is essential to realize that accurate time and temperature controls must be in place for the hot water treatment to be successful. The temperature for pathogen inactivation must not exceed the critical damage threshold for the propagative material being disinfested. 


\section{Biological Control}

The use of beneficial microorganisms to suppress soilborne and foliar plant pathogens is known as biological control. Products containing bacteria such as Bacillus, Pseudomonas, and Streptomyces and fungi such as Gliocladium and Trichoderma have reduced a variety of fungal plant pathogens in various experiments, especially when incorporated into transplant media or used as seed treatments. Products containing biological control agents that are currently available for disease management of ornamentals are listed in Table 3, along with the active organism(s) and disease applications. Ongoing research at universities and federal facilities continues to evaluate and develop new biocontrols as well as expand the labeling of existing products. The use of organic soil amendments (e.g. compost, sewage sludge, etc.) may enhance populations of beneficial microorganisms already present in the soil. Biological control technologies are environmentally friendly IPM tools with great potential, but currently biological controls do not adequately control ornamental plant diseases on their own in most cases.

\section{Chemical Control}

Regardless of what other IPM strategies are used, it is sometimes necessary to apply chemical pesticides (i.e. fungicides, bactericides, etc.) to manage plant diseases. Pesticide application should be based on scouting reports and the presence of environmental conditions conducive to disease development in established planting systems. Avoid using routine "calendar sprays" which can be wasteful and destroy populations of beneficial organisms.

Pesticides may be applied to ornamental plants in a granular form, a liquid foliar spray, or a drench. Most chemicals used in disease management are applied as sprays or dusts aimed at fungal pathogens on leaves and other aboveground plant parts.

Pesticides may be applied before planting to soil and planting stock in a drench or dip, respectively. Gaseous soil fumigants are sometimes applied as a preplant treatment in mass plant production systems and kill most organisms in the soil including fungi, bacteria, nematodes, and weed seed. Fumigants are highly toxic; therefore, extreme safety precautions must be taken to protect workers.

\section{Choosing a Pesticide}

Correct identification of a target disease and pathogen is essential to choosing an appropriate pesticide for its control (see "scouting"). Some products kill only certain pathogens, while others are effective against a broad range of organisms. A chemical can be chosen from Table 1 based on the disease group, which describes one or more of the following: the type of symptom exhibited by the plant (e.g. blight, scab, rot), part of plant affected (e.g. flower, leaf, root, etc.), type of pathogen causing the disease (e.g. downy mildew, powdery mildew, etc.), or the specific pathogen causing the disease (e.g. Phytophthora, Stromatinia, etc.). Disease groups describing general symptoms (i.e. leaf spots, blights, scabs) may be caused by many different pathogens. It is not likely that every chemical listed for such disease groups will control every possible pathogen for that disease group. Chemicals labeled for each disease group are listed by common name. The common name is the active ingredient contained within a product, which is sold under a trade name. For example, azoxystrobin (common name) is the active ingredient in the fungicide Heritage (trade name). The chemical class represents either the chemical structure or mode of action of the active ingredient to which each chemical belongs. Rotation of chemicals in different classes is important in slowing the development of resistant pest populations.

Trade names available for each chemical in Table 1 are listed in Table 2, along with the activity of each. There is usually more than one product available for each active ingredient and some products contain more than one chemical. The activity of a chemical refers to its mobility in the plant, and should be considered when choosing a product. Systemic fungicides (S) usually move upward within a plant, though there are a few that also move downward. They may be applied as foliar sprays, seed treatments, root dips, soil drenches, or tree injections. Locally systemic fungicides (LS) have limited mobility in the direct vicinity of application. 
Almost all systemic fungicides disrupt only one or a few steps in fungal metabolism. Therefore, resistance to these chemicals usually occurs within a few years if used frequently. It is best to use these products in combination or rotation with broad-spectrum contact fungicides to delay development of resistance. Advantages of using systemic fungicides include longer residual activity and survival of possible beneficial organisms on the plant surface. Contact fungicides may have protective or curative activity. Most fungicides and bactericides are protectants (P) and must be present on the surface of the plant in advance of the pathogen in order to prevent infection. These chemicals may be applied when environmental conditions are conducive to a disease outbreak. Products with curative activity (C) may be applied after the onset of disease. Some chemicals have both protective and curative activity that may depend on the rate of application. Resistance to many contact pesticides is slow to develop or non-existent because many different metabolic pathways of target organisms are disrupted. Keep in mind that the overuse of these products may also reduce populations of beneficial organisms (i.e. biological controls).

Not all ornamental pesticides may be applied to all ornamental plants depending on phytotoxicity and location of the plant. Most pesticide labels have a list of plants on which the product has been tested and determined safe to treat, as well as plants not tolerant of the product. It is a good idea to test unfamiliar products on a few plants before applying it on a large scale to prevent loss. Products in Table 2 with bold font are legal to use on plants not listed on the label if tested and found to be safe in small-scale trials.

\section{Pesticide Performance}

Insufficient coverage is one of the most common reasons for pesticide failure. Calibrate sprayers on a regular basis and maintain them in good working order to get the best performance and coverage. Many pesticides are broken down (hydrolyzed) when mixed with water above $\mathrm{pH} 7$. Be aware of the water $\mathrm{pH}$ and when above 7 use an appropriate buffering solution in the tank to maintain $\mathrm{pH}$ in the 6.5 to 7 range. For safety and efficacy, pesticides should be applied the same day they are mixed with water.
Phytotoxic effects characterized by marginal leaf scorch, leaf spotting, or distortion of new growth may occur if pesticides are applied too heavily, under extremely hot or dry conditions (water-stressed plants), inappropriately mixed with a spreader-sticker, or in an incompatible mixture (see "tank mixtures"). Damage can be highly variable depending on plant species and chemical applied.

Pesticide performance is sometimes altered by the development of pathogen resistance, which may develop if the same chemical, chemicals within the same class, or with similar modes of action are applied repeatedly over a long period of time. Once resistance to a particular pesticide builds up within a pest population, other products may also be rendered ineffective (i.e. cross resistance). Modes of action for each chemical class, along with resistance risk, are listed in Table 4. Chemical classes with multiple-site modes of action generally pose the least risk for the development of pathogen resistance. It is wise to use rotations of chemicals within these classes, especially when using ones of high resistance risk. Fungicide labels often have specific recommendations on resistance management which should be rigorously followed.

\section{Tank Mixtures}

Spray tank mixtures of different pesticides (i.e. fungicides, insecticides, miticides, etc.) and even fertilizers may be chemically incompatible, resulting in plant injury that does not occur if any one of the products is used alone. When applying a new mix, test on a few plants and wait 24-48 hours for signs of phytotoxicity prior to large-scale use. Physical incompatibility is also possible if combining products does not result in a uniform mixture (i.e. clumping). Products with similar formulations, classes, or made by the same company may be more compatible; however, always refer to the labels and/or a compatibility chart before tank mixing.

A spreader-sticker may be added to the spray mixture to obtain better coverage and residual persistence of a pesticide. Note that some ornamental plants may be sensitive to spreader-stickers and other additives. Check the label for restrictions. If in doubt, test for safety on a few plants before widespread use. 
Mixing by mechanical agitation in the spray tank is often necessary to attain best results.

\section{References}

Chase, A. R., M. L. Daughtrey, and G. W. Simone (eds.). 1995. Diseases of Annuals and Perennials. G. J. Ball Pub. Co., Batavia, IL.

Chase, A. R. 1987. Compendium of Ornamental Foliage Plant Diseases. A. R. Chase, APS Press, St Paul MN.

Daughtrey, M. L., R. L. Wick, and J. L. Peterson (eds.). 1995. Compendium of Flowering Potted Plant Diseases. APS Press, St. Paul, MN.

Daughtrey, M. and A. R. Chase. 1992. Ball Field Guide to Diseases of Greenhouse Ornamentals.

G. J. Ball Pub. Co., Batavia, IL.

Elliott, M. L., T. K. Broschat, J. Y. Uchida, and G. W. Simone (eds.). 2004. Compendium of Ornamental Palm Diseases and Disorders. APS Press, St. Paul, Minnesota.

Hansen, E. M., and K. J. Lewis. 1997. Compendium of Conifer Diseases. APS Press, St. Paul, MN.

Jones, R. K., and D. M. Benson. 2001. Diseases of Woody Ornamentals and Trees in Nurseries. APS Press, St. Paul, MN.

Short, D. E., G. W. Simone, and R. A. Dunn, 2001. Commercial Ornamental Nursery Scouting Manual. University of Florida-IFAS Extension Publication SP 235, Gainesville, FL.

Horst, R. K. 1983. Compendium of Rose Diseases. APS Press, St. Paul, MN.

Horst, R. K, and P. E. Nelson (eds.). 1997. Compendium of Chrysanthemum Disease. APS Press, St. Paul, MN.

\section{Useful Websites}

Care of Ornamental Plants in the Landscape (fertilization) http://pubs.caes.uga.edu/caespubs/pubcd/ B1065.htm

Distance Diagnostic Identification System http://edis.ifas.ufl.edu/TOPIC_DDIS

EDIS homepage http://edis.ifas.ufl.edu/

Florida Crop/Pest Management Profiles: Ornamentals http://edis.ifas.ufl.edu/PI038

Harpin fact sheet (EPA) http://www.epa.gov/pesticides/biopesticides/ ingredients/factsheets/factsheet_006477.htm

IPM Florida http://ipm.ifas.ufl.edu/

Key for Identifying Landscape Turfgrass Disease http://edis.ifas.ufl.edu/LH064

Landscape Plants http://edis.ifas.ufl.edu/TOPIC_Landscape_Plants

Landscape Plants for Wet Sites http://www.ces.ncsu.edu/depts/hort/hil/hil-646.html

Ornamental Pest Management at Ft. Lauderdale REC http://flrec.ifas.ufl.edu/entomo/Ornamental_Pests/ ornapest.htm

Plant Information Databases

http://hort.ifas.ufl.edu/database/databases.htm

(Nutrient deficiencies, propagation, tree $\&$ shrub fact sheets)

Planting trees in landscapes by Ed Gilman http://hort.ifas.ufl.edu/woody/planting/ (tree \& shrub planting, production, pruning, and more)

Selecting and Planting Trees and Shrubs http://edis.ifas.ufl.edu/MG077

Weed Management Guide http://edis.ifas.ufl.edu/ TOPIC_GUIDE_Weed_Management_Guide

Woody Ornamentals http://hort.ifas.ufl.edu/woody/index.htm 


\section{Attention}

Always read, understand, and follow all label instructions including safety precautions, required personal protective equipment (PPE), range of target organisms, rates of application, risks of phytotoxicity, and compatibility with other chemicals before application. 
Table 1. Chemicals used to manage diseases of ornamental plants. ${ }^{a}$

\begin{tabular}{|c|c|c|}
\hline Disease group $^{d}$ & Chemical common name & Chemical class \\
\hline \multirow{32}{*}{$\begin{array}{l}\text { Fungal foliar blights and } \\
\text { leaf spots }\end{array}$} & azoxystrobin & Qol (strobilurin) \\
\hline & captan & phthalimide \\
\hline & chlorothalonil & benzonitrile \\
\hline & chlorothalonil + fenarimol & benzonitrile + DMI (pyrimidine) \\
\hline & chlorothalonil + thiophanate methyl & benzonitrile + benzimidazole \\
\hline & chlorothalonil + zinc & benzonitrile + inorganic \\
\hline & copper hydroxide & inorganic \\
\hline & copper hydroxide + mancozeb & inorganic $+\mathrm{EBDC}^{\mathrm{C}}$ \\
\hline & copper oxychloride & inorganic \\
\hline & copper sulfate & inorganic \\
\hline & copper sulphate pentahydrate & inorganic \\
\hline & dicloran & nitroaniline \\
\hline & dimethomorph + mancozeb & cinnamic acid+ EBDC \\
\hline & fenhexamide & hydroxyanilide \\
\hline & ferbam & dithiocarbamate \\
\hline & fludioxonil & phenylpyrrole \\
\hline & flutolanil & carboxamide \\
\hline & iprodione & dicarboximide \\
\hline & kresoxim-methyl & Qol (strobilurin) \\
\hline & mancozeb & EBDC \\
\hline & maneb & EBDC \\
\hline & myclobutanil & DMI (triazole) \\
\hline & neem oil extract & lipid \\
\hline & PCNB & substituted aromatic \\
\hline & potassium bicarbonate & bicarbonate \\
\hline & propiconazole & DMI (triazole) \\
\hline & sulfur & inorganic \\
\hline & thiophanate methyl & benzimidazole \\
\hline & triadimefon & DMI (triazole) \\
\hline & trifloxystrobin & Qol (strobilurin) \\
\hline & triflumizole & DMI (imidazole) \\
\hline & vinclozolin & dicarboximide \\
\hline \multirow[t]{8}{*}{ Phytophthora blight } & azoxystrobin & Qol (strobilurin) \\
\hline & chlorothalonil & benzonitrile \\
\hline & chlorothalonil + thiophanate methyl & benzonitrile + benzimidazole \\
\hline & chlorothalonil + zinc & benzonitrile \\
\hline & dimethomorph + mancozeb & cinnamic acid+ dithiocarbamate \\
\hline & fosetyl-aluminum & phosphonates \\
\hline & mancozeb & EBDC \\
\hline & phosphorous acid & phosphonates \\
\hline \multirow{6}{*}{$\begin{array}{l}\text { Bacterial leaf spots, } \\
\text { blights }\end{array}$} & copper hydroxide & inorganic \\
\hline & copper sulphate pentahydrate & inorganic \\
\hline & copper hydroxide + mancozeb & inorganic + EBDC \\
\hline & copper sulfate & inorganic \\
\hline & fosetyl-aluminum & phosphonates \\
\hline & phosphorous acid & phosphonates \\
\hline
\end{tabular}


Table 1. Chemicals used to manage diseases of ornamental plants. ${ }^{a}$

\begin{tabular}{|c|c|c|}
\hline Disease group $^{d}$ & Chemical common name & Chemical class \\
\hline \multirow[t]{3}{*}{ Bacterial soft rot } & copper hydroxide & inorganic \\
\hline & copper sulphate pentahydrate & inorganic \\
\hline & streptomycin sulfate & antibiotic \\
\hline \multirow[t]{12}{*}{ Downy mildew } & azoxystrobin & Qol (strobilurin) \\
\hline & copper hydroxide & inorganic \\
\hline & copper sulphate pentahydrate & inorganic \\
\hline & chlorothalonil + thiophanate methyl & benzonitrile + benzimidazole \\
\hline & dimethomorph + mancozeb & cinnamic acid+dithiocarbamate \\
\hline & fosetyl-aluminum & phosphonates \\
\hline & kresoxim-methyl & Qol (strobilurin) \\
\hline & mancozeb & EBDC \\
\hline & maneb & EBDC \\
\hline & neem oil extract & lipid \\
\hline & phosphorous acid & phosphonates \\
\hline & trifloxystrobin & Qol (strobilurin) \\
\hline \multirow[t]{21}{*}{ Powdery mildew } & azoxystrobin & Qol (strobilurin) \\
\hline & chlorothalonil & benzonitrile \\
\hline & chlorothalonil + fenarimol & benzonitrile + DMI (pyrimidine) \\
\hline & chlorothalonil + thiophanate methyl & benzonitrile + benzimidazole \\
\hline & chlorothalonil + zinc & benzonitrile \\
\hline & copper hydroxide & inorganic \\
\hline & copper oxychloride & inorganic \\
\hline & copper sulfate & inorganic + sulfur \\
\hline & fenarimol & DMI (pyrimidine) \\
\hline & kresoxim-methyl & Qol (strobilurin) \\
\hline & myclobutanil & DMI (triazole) \\
\hline & neem oil extract & lipid \\
\hline & piperalin & piperidines \\
\hline & potassium bicarbonate & bicarbonate \\
\hline & potassium salts of fatty acids & insecticidal soap \\
\hline & propiconazole & DMI (triazole) \\
\hline & sulfur & inorganic \\
\hline & thiophanate methyl & benzimidazole \\
\hline & triadimefon & DMI (triazole) \\
\hline & trifloxystrobin & Qol (strobilurin) \\
\hline & triflumizole & DMI (imidazole) \\
\hline
\end{tabular}


Table 1. Chemicals used to manage diseases of ornamental plants. ${ }^{a}$

\begin{tabular}{|c|c|c|}
\hline Disease group $^{d}$ & Chemical common name & Chemical class \\
\hline \multirow[t]{15}{*}{ Petal, flower blights } & captan & dicarboximide \\
\hline & chlorothalonil & benzonitrile \\
\hline & chlorothalonil + fenarimol & benzonitrile + DMI (pyrimidine) \\
\hline & chlorothalonil + thiophanate methyl & benzonitrile + benzimidazole \\
\hline & chlorothalonil + zinc & benzonitrile \\
\hline & dimethomorph + mancozeb & cinnamic acid+ EBDC \\
\hline & ferbam & dithiocarbamate \\
\hline & iprodione & dicarboximide \\
\hline & mancozeb & EBDC \\
\hline & maneb & EBDC \\
\hline & myclobutanil & DMI (triazole) \\
\hline & neem oil extract & lipid \\
\hline & PCNB & substituted aromatic \\
\hline & propiconazole & DMI (triazole) \\
\hline & triadimefon & DMI (triazole) \\
\hline \multirow[t]{22}{*}{ Rusts } & azoxystrobin & Qol (strobilurin) \\
\hline & chlorothalonil & benzonitrile \\
\hline & chlorothalonil + fenarimol & benzonitrile + DMI (pyrimidine) \\
\hline & chlorothalonil + thiophanate methyl & benzonitrile + benzimidazole \\
\hline & chlorothalonil + zinc & benzonitrile \\
\hline & copper hydroxide + mancozeb & inorganic + EBDC \\
\hline & dimethomorph + mancozeb & cinnamic acid+ EBDC \\
\hline & fenarimol & DMI (pyrimidine) \\
\hline & ferbam & dithiocarbamate \\
\hline & flutolanil & carboxamide \\
\hline & kresoxim-methyl & Qol (strobilurin) \\
\hline & mancozeb & EBDC \\
\hline & maneb & EBDC \\
\hline & myclobutanil & DMI (triazole) \\
\hline & neem oil extract & lipid \\
\hline & oxycarboxin & carboxamide \\
\hline & propiconazole & DMI (triazole) \\
\hline & sulfur & inorganic \\
\hline & thiophanate methyl & benzimidazole \\
\hline & triadimefon & DMI (triazole) \\
\hline & trifloxystrobin & Qol (strobilurin) \\
\hline & triflumizole & DMI (triazole) \\
\hline
\end{tabular}


Table 1. Chemicals used to manage diseases of ornamental plants. ${ }^{a}$

\begin{tabular}{|c|c|c|}
\hline Disease group $^{d}$ & Chemical common name & Chemical class \\
\hline \multirow[t]{13}{*}{ Scabs } & azoxystrobin & Qol (strobilurin) \\
\hline & chlorothalonil & benzonitrile \\
\hline & chlorothalonil + fenarimol & benzonitrile + DMI (pyrimidine) \\
\hline & chlorothalonil + thiophanate methyl & benzonitrile + benzimidazole \\
\hline & chlorothalonil + zinc & benzonitrile \\
\hline & dimethomorph + mancozeb & cinnamic acid+ EBDC \\
\hline & fenarimol & DMI (pyrimidine) \\
\hline & kresoxim-methyl & Qol (strobilurin) \\
\hline & mancozeb & EBDC \\
\hline & myclobutanil & DMI (triazole) \\
\hline & potassium bicarbonate & bicarbonate \\
\hline & thiophanate methyl & benzimidazole \\
\hline & triflumizole & DMI (triazole) \\
\hline \multirow[t]{6}{*}{ Cylindrocladium root rot } & chlorothalonil + thiophanate methyl & benzonitrile + benzimidazole \\
\hline & dimethomorph + mancozeb & cinnamic acid+ dithiocarbamate \\
\hline & fludioxonil & phenylpyrrole \\
\hline & iprodione & dicarboximide \\
\hline & thiophanate methyl & benzimidazole \\
\hline & triflumizole & DMI (triazole) \\
\hline \multirow{7}{*}{$\begin{array}{l}\text { Fusarium rot (root, bulb, } \\
\text { etc.) \& wilt }\end{array}$} & azoxystrobin & Qol (strobilurin) \\
\hline & chlorothalonil + thiophanate methyl & benzonitrile + benzimidazole \\
\hline & fludioxonil & phenylpyrrole \\
\hline & iprodione & dicarboximide \\
\hline & thiabendazole & benzimidazole \\
\hline & thiophanate methyl & benzimidazole \\
\hline & triflumizole & DMI (triazole) \\
\hline \multirow[t]{2}{*}{ Gliocladium rot } & chlorothalonil + thiophanate methyl & benzonitrile + benzimidazole \\
\hline & thiophanate methyl & benzimidazole \\
\hline \multirow{3}{*}{$\begin{array}{l}\text { Myrothecium stem, } \\
\text { crown, root rot }\end{array}$} & chlorothalonil + thiophanate methyl & benzonitrile + benzimidazole \\
\hline & thiophanate methyl & benzimidazole \\
\hline & trifloxystrobin & Qol (strobilurin) \\
\hline \multirow{6}{*}{$\begin{array}{l}\text { Pythium, Phytophthora } \\
\text { rot }\end{array}$} & captan & dicarboximide \\
\hline & etridiazole & thiadiazole \\
\hline & fosetyl-aluminum & phosphonates \\
\hline & mefenoxam & phenylamide \\
\hline & phosphorous acid & phosphonates \\
\hline & propamocarb hydrochloride & carbamate \\
\hline \multirow[t]{8}{*}{ Rhizoctonia rot } & azoxystrobin & Qol (strobilurin) \\
\hline & chlorothalonil + thiophanate methyl & benzonitrile + benzimidazole \\
\hline & fludioxonil & phenylpyrrole \\
\hline & flutolanil & carboxamide \\
\hline & iprodione & dicarboximide \\
\hline & PCNB & substituted aromatic \\
\hline & thiophanate methyl & benzimidazole \\
\hline & triflumizole & DMI (triazole) \\
\hline
\end{tabular}


Table 1. Chemicals used to manage diseases of ornamental plants. ${ }^{a}$

\begin{tabular}{|c|c|c|}
\hline Disease group $^{d}$ & Chemical common name & Chemical class \\
\hline \multirow{3}{*}{$\begin{array}{l}\text { Sclerotinia blight, stem } \\
\text { rot }\end{array}$} & PCNB & substituted aromatic \\
\hline & thiophanate methyl & benzimidazole \\
\hline & vinclozolin & dicarboximide \\
\hline \multirow{4}{*}{$\begin{array}{l}\text { Sclerotium blight, stem } \\
\text { rot }\end{array}$} & azoxystrobin & Qol (strobilurin) \\
\hline & fludioxonil & phenylpyrrole \\
\hline & flutolanil & carboxamide \\
\hline & PCNB & substituted aromatic \\
\hline \multirow[t]{2}{*}{ Stromatinia rot } & PCNB & substituted aromatic \\
\hline & vinclozolin & dicarboximide \\
\hline \multirow[t]{3}{*}{ Thielaviopsis root rot } & fludioxonil & phenylpyrrole \\
\hline & thiophanate methyl & benzimidazole \\
\hline & triflumizole & DMI (triazole) \\
\hline Algae $^{b}$ & copper hydroxide + mancozeb & inorganic + EBDC \\
\hline \multicolumn{3}{|c|}{$\begin{array}{l}\text { a There may be several commercial products available for each chemical. Always check th } \\
\text { the product is appropriate for particular plants and/or locations. } \\
{ }^{b} \text { Algae growth is typically an aesthetic problem and not a disease. } \\
{ }^{c} \text { Dithiocarbamates and relatives including ethylene bis-dithiocarbamate (EBDC). } \\
{ }^{d} \text { Check label for specific range of activity of each chemical listed within a disease group. }\end{array}$} \\
\hline
\end{tabular}

Table 2. Commercial products that contain one or more chemicals listed in Table 1. ${ }^{a}$

\begin{tabular}{|l|l|l||}
\hline \hline Chemical or combination & Trade names & Activity $^{\mathbf{b}^{\prime}}$ \\
\hline azoxystrobin & Heritage & $\mathrm{S}, \mathrm{P}, \mathrm{C}$ \\
\hline captan & Captan 50W & $\mathrm{P}$ \\
\hline chlorothalonil & $\begin{array}{l}\text { Chlorostar VI F, Concorde DF, Daconil, Manicure, } \\
\text { Chlorothalonil DF, Echo 720 }\end{array}$ & $\mathrm{P}$ \\
\hline chlorothalonil + fenarimol & Twosome Flowable Fungicide & LS, $\mathrm{P}$ \\
\hline $\begin{array}{l}\text { chlorothalonil + thiophanate } \\
\text { methyl }\end{array}$ & Spectro 90WG, Consyst WDG & $\mathrm{S}, \mathrm{P}, \mathrm{C}$ \\
\hline chlorothalonil + zinc & Daconil Zn & $\mathrm{P}$ \\
\hline copper hydroxide & Champion WP, Kocide 2000 TNO, etc. & $\mathrm{P}$ \\
\hline copper hydroxide + mancozeb & Junction & $\mathrm{P}$ \\
\hline copper oxychloride & COC DF, COC WP & $\mathrm{P}$ \\
\hline copper sulfate & Basicop & $\mathrm{P}$ \\
\hline Copper sulphate pentahydrate & Phyton 27 & $\mathrm{P}$ \\
\hline dicloran & Botran 75W & $\mathrm{P}$ \\
\hline dimethomorph + mancozeb & Stature WP & LS, P, C \\
\hline etridiazole & Terrazole & $\mathrm{P}$ \\
\hline fenarimol & Rubigan AS & $\mathrm{S}, \mathrm{P}, \mathrm{C}$ \\
\hline ferbam & Ferbam Granuflo & $\mathrm{P}$ \\
\hline \hline
\end{tabular}


Table 2. Commercial products that contain one or more chemicals listed in Table $1 .^{a}$

\begin{tabular}{|c|c|c|}
\hline Chemical or combination & Trade names & Activity $^{\mathrm{b}}$ \\
\hline fludioxonil & Medallion & $\mathrm{P}$ \\
\hline flutolanil & Prostar 70 WP, Contrast 70 WSP & $\mathrm{S}, \mathrm{P}, \mathrm{C}$ \\
\hline fosetyl-aluminum & Aliette WDG & $S^{C}, P$ \\
\hline iprodione & Chipco 26GT & LS, $P$ \\
\hline kresoxim-methyl & Cygnus & $\mathrm{S}, \mathrm{P}, \mathrm{C}$ \\
\hline mancozeb & $\begin{array}{l}\text { Dithane T/O, Fore Rainshield, Pentathlon DF, } \\
\text { Protect } \mathrm{T} / \mathrm{O}\end{array}$ & $\mathrm{P}$ \\
\hline maneb & Pentathlon & $\mathrm{P}$ \\
\hline mefenoxam & Subdue MAXX, Mefenoxam 2 & $\mathrm{~S}, \mathrm{P}, \mathrm{C}$ \\
\hline myclobutanil & Eagle 40WP, Systhane WSP & $\mathrm{S}, \mathrm{P}, \mathrm{C}$ \\
\hline neem oil extract & Triact 70 & $\mathrm{P}, \mathrm{C}$ \\
\hline oxycarboxin & Plantvax 75W & $\mathrm{S}, \mathrm{P}, \mathrm{C}$ \\
\hline PCNB & Blocker 4F, Revere 10G, Terraclor, Turfcide & $\mathrm{P}$ \\
\hline phosphorous acid & Alude, Fosphite, Magellan & $\mathrm{S}, \mathrm{P}$ \\
\hline piperalin & Pipron & $\mathrm{S}, \mathrm{P}, \mathrm{C}$ \\
\hline potassium bicarbonate & Armicarb 100, Kaligreen & $\mathrm{P}$ \\
\hline insecticidal soap & M-Pede & $\mathrm{P}$ \\
\hline propamocarb hydrochloride & Banol & $\mathrm{S}, \mathrm{P}$ \\
\hline propiconazole & Banner Maxx, Propiconazole Pro & $\mathrm{S}, \mathrm{P}, \mathrm{C}$ \\
\hline streptomycin sulfate & Agrimycin 17 & $\mathrm{P}$ \\
\hline sulfur & Sulfur 6L, Sulfur 90W, Microthiol Disperss, etc. & $\mathrm{P}$ \\
\hline thiabendazole & Mertect 340-F & LS, P, C \\
\hline thiophanate methyl & Cavalier Flowable, Cleary's 3336, Fungo 50, etc. & LS, P, C \\
\hline triadimefon & Bayleton 50, Strike 50 WDG & $\mathrm{S}, \mathrm{P}, \mathrm{C}$ \\
\hline trifloxystrobin & Compass & $\mathrm{LS}, \mathrm{P}, \mathrm{C}$ \\
\hline triflumizole & Terraguard 50W & $\mathrm{S}, \mathrm{P}, \mathrm{C}$ \\
\hline vinclozolin & Touche EG & $\mathrm{LS}, \mathrm{P}, \mathrm{C}$ \\
\hline \multicolumn{3}{|c|}{$\begin{array}{l}\text { a Trade names are listed only for example. No endorsement or criticism of any product is intended by } \\
\text { its presence or absence from this table. Labels of products listed in bold font allow use on ornamental } \\
\text { plants not listed if tested and found to be safe by the applicator. Always read and follow pesticide label } \\
\text { instructions. } \\
{ }^{b} \text { Movement into the plant and type of control: } S=\text { upward systemic, LS = local systemic, } P= \\
\text { protective, } C=\text { curative } \\
{ }^{c} \text { Fosetyl-aluminum is the only fungicide in the table with upward and downward systemic movement. }\end{array}$} \\
\hline
\end{tabular}

Table 3. Selected biological control products and reported disease applications ${ }^{a}$

\begin{tabular}{||l|l|l||}
\hline \hline Product & Organism & Disease applications \\
\hline Actinovate & Streptomyces lydicus & soilborne diseases \\
\hline AQ-10 & Ampelomyces quisqualis & powdery mildew control \\
\hline Binab TF WP & $\begin{array}{l}\text { Trichoderma polysporum and T. } \\
\text { harzianum }\end{array}$ & controls a variety of fungal pathogens \\
\hline BlightBan A506 & Pseudomonas fluorescens A506 & Erwinia amylovora; fireblight \\
\hline \hline
\end{tabular}


Table 3. Selected biological control products and reported disease applications ${ }^{a}$

\begin{tabular}{|c|c|c|}
\hline Product & Organism & Disease applications \\
\hline Companion, Kodiak & Bacillus subtilis & $\begin{array}{l}\text { soilborne diseases (Rhizoctonia, } \\
\text { Phythium, Fusarium, Phytophthora, } \\
\text { Sclerotinia, Anthracnose, Botrytis) }\end{array}$ \\
\hline Contans & Coniothyrium minitans & soilborne Sclerotinia spp. \\
\hline Galltrol-A & Agrobacterium radiobacter 1026 & prevents crown gall \\
\hline Mycostop & Streptomyces sp. & $\begin{array}{l}\text { wilt and root rot caused by Pythium, } \\
\text { Fusarium, Botrytis, Alternaria, Phomopsis, } \\
\text { and to a lesser extent, Phythophthora and } \\
\text { Rhizoctonia. }\end{array}$ \\
\hline PlantShield & Trichoderma harzianum & $\begin{array}{l}\text { preventative control of foliar and root } \\
\text { fungal diseases }\end{array}$ \\
\hline Rhapsody AS & Bacillus subtilis QST 713 Strain & $\begin{array}{l}\text { Anthracnose (Colletotrichum spp.), } \\
\text { bacteria (Erwinia, Pseudomonas, } \\
\text { Xanthomonas)., black spot (Diplocarpon } \\
\text { rosae), Botrytis cinerea, fungal leaf spots, } \\
\text { and powdery mildew }\end{array}$ \\
\hline RootShield & Trichoderma harzianum strain T-22 & $\begin{array}{l}\text { Prevention of root rot caused by Pythium, } \\
\text { Rhizoctonia, and Fusarium. }\end{array}$ \\
\hline SoilGard 12G & Gliocladium virens GL-21 & $\begin{array}{l}\text { control of damping off and root rot } \\
\text { organisms }\end{array}$ \\
\hline
\end{tabular}

Table 4. Mode of action and resistance risk for each chemical class ${ }^{\mathrm{a}}$.

\begin{tabular}{|c|c|c|}
\hline Chemical Class & Target & Resistance Risk \\
\hline benzimidazole & Cell mitosis & High \\
\hline benzonitrile & Multi-site & Low \\
\hline bicarbonate & Unknown & Unknown \\
\hline carbamate & Cell membrane & Low to medium \\
\hline carboxamide & Fungal respiration & Moderate \\
\hline cinnamic acid & Cell wall synthesis (proposed) & Low to medium \\
\hline dicarboximide & Lipid peroxidation & Moderate to high \\
\hline Dithiocarbamate, EBDC & Multi-site & Low \\
\hline DMI (demethylation inhibitor) & Sterol biosynthesis & Medium \\
\hline hydroxyanilide & Sterol biosynthesis & Low to medium \\
\hline inorganic & Multi-site & Low \\
\hline lipid & Unknown & Unknown \\
\hline nitroaniline & Lipid peroxidation & Low to medium \\
\hline phenylamide & RNA polymerase & High \\
\hline phenylpyrrole & MAP protein kinase & Low to medium \\
\hline phosphonates & Unknown & Assumed low \\
\hline phthalimide & Multi-site & Low \\
\hline piperidines & Sterol biosynthesis & Low to medium \\
\hline Qol (quinone outside inhibitor) or strobilurin & Fungal respiration & High \\
\hline substituted aromatic & Lipid peroxidation & Low to medium \\
\hline thiadiazole & Lipid peroxidation & Low to medium \\
\hline
\end{tabular}


Table 4. Mode of action and resistance risk for each chemical class ${ }^{a}$.

\begin{tabular}{||l|l|l||}
\hline \hline Chemical Class & Target & Resistance Risk \\
\hline${ }^{a}$ Information compiled from Fungicide Resistance Action Committee website: http://www.frac.info \\
\hline
\end{tabular}

